\begin{tabular}{|l|l|l||}
\hline \multicolumn{2}{|c|}{ PublisherInfo } \\
\hline \hline PublisherName & $:$ & BioMed Central \\
\hline \hline PublisherLocation & $:$ & London \\
\hline \hline PublisherImprintName & $:$ & BioMed Central \\
\hline \hline
\end{tabular}

\title{
Combination therapy for lupus nephritis
}

\begin{tabular}{|l|l|l||}
\hline \multicolumn{2}{|c|}{ ArticleInfo } \\
\hline \hline ArticleID & $:$ & 96 \\
\hline \hline ArticleDOI & $:$ & $10.1186 /$ ar-2001-68059 \\
\hline \hline ArticleCitationID & $:$ & 68059 \\
\hline \hline ArticleSequenceNumber & $:$ & 53 \\
\hline \hline ArticleCategory & $:$ & Paper Report \\
\hline \hline ArticleFirstPage & $:$ & 1 \\
\hline \hline ArticleLastPage & $:$ & 3 \\
\hline \hline & & RegistrationDate $: 2001-4-24$ \\
& $:$ & Received \\
ArticleHistory & $:$ & Accepted \\
& & OnlineDate $2001-7-26$ \\
\hline \hline ArticleCopyright & $:$ & Biomed Central Ltd2001 \\
\hline \hline ArticleGrants & $:$ & \\
\hline \hline
\end{tabular}




\begin{tabular}{|l|l|l|l|}
\hline ArticleContext & $:$ & 130753311 \\
\hline
\end{tabular}

Anne Barton, ${ }^{\text {Aff1 }}$

Aff1 University of Menchester, UK

Keywords

CTLA4, cyclophosphamide, nephritis, SLE, treatment

\section{Context}

The efficacy of using cyclophosphamide (CTX) to slow progression of lupus nephritis was first demonstrated in the B/W mouse model of the disease. Subsequent studies showed CTX to be beneficial in humans with lupus nephritis. CTX is an alkylating agent that damages DNA repair mechanisms. Cytotoxic T lymphocyte associated antigen (CTLA) 4 is a co-stimulatory protein required for T cell activation. Previous work has shown that administration of CTLA4-Ig prevents the progression of lupus nephritis and improves survival in $\mathrm{B} / \mathrm{W}$ mice. The current study investigated the possibility that administration of CTX and CTLA4-Ig together may have beneficial effects on the course of lupus nephritis in $\mathrm{B} / \mathrm{W}$ mice over and above the effect of either agent alone.

\section{Significant findings}

In mice with severe and in mice with mild nephritis, CTLA4-Ig was as effective as CTX for the treatment of lupus nephritis. However, administration of a combination of CTX and CTLA4-Ig improved the level of proteinuria and survival compared to animals treated with either agent alone. Following cessation of treatment, there was progression of renal disease and mortality in all treatment groups although survival was greater in the group treated with combination therapy. CTX caused a significant decline in the number of B cells whilst CTLA4-Ig administration increased the number of $\mathrm{CD}^{+} \mathrm{T}$ cells, suggesting that the two agents modulate different pathways in the pathogenesis of lupus nephritis. This may explain the synergistic benefit of combining the two agents.

\section{Comments}


In this animal model of lupus nephritis, it has been shown that administration of CTLA4-Ig has similar efficacy to treatment with CTX. Furthermore, a combination of these two agents was better than treatment with either agent alone. The cyclophosphamide was administered intraperitonelly at a dose of $50 \mathrm{mg} / \mathrm{kg}$ every 10 days compared to doses used in humans, which are 1-3 mg/kg orally daily or $0.5-1.0$ $\mathrm{g} / \mathrm{m}^{2}$ intravenously, usually on a monthly basis. Clinical trials to assess the efficacy of combination therapy in the treatment of lupus nephritis in humans may now be indicated.

\section{Methods}

Female B/W mice, intraperitoneal administration, ELISA for dsDNA antibody measurement, Uristix Ames reagent strips for assessment of proteinuria, flow cytometry

\section{Additional information}

\section{References}

1. Daikh DI, Wofsy D: Cutting edge: reversal of murine lupus nephritis with CTLA4Ig and cyclophosphamide. J Immunol. 2001, 166: 2913-2916.

This PDF file was created after publication. 